\title{
Evaluation of Asia and Decolonization in the US Press
}

\author{
S. O. Buranok
}

For citation: Buranok S. O. Evaluation of Asia and Decolonization in the US Press. Vestnik of Saint Petersburg University. History, 2020, vol. 65, issue 4, pp. 1186-1201.

https://doi.org/10.21638/11701/spbu02.2020.410

No research in the colonial system issues during the Cold War would be complete without studying the press of the participating parties. In order to give a detailed analysis of the international relationships in terms of the global transformations from an American point of view, the article explores relevant newspaper articles published after the World War II. It shows changes concerning priority schemes as viewed in American social discourse during 1945. Roosevelt's plan for the dismantling of the colonial empires was gradually replaced with less radical plans, which presupposed using the colonial experience for foreign policy of the USA. The materials of the American press of 1945 dedicated to the search for the most effective strategy of building relations with both colonial empires and dependent territories demonstrate, among other things, a steady interest of American mass media in negative and positive experience of colonial policy. Thus, in the American public discourse of late 1945 emerged several new approaches towards evaluation of the prospects of the colonial system. The first approach: retention of all colonial empires, especially in the key points of the after-war world (Middle East, Indochina, Northern Africa). The second approach: retention of the British colonial empire capable of controlling (with the aid from the USA) the Mediterranean area, the Middle East, and the South-Eastern Asia; which would address two tasks, namely provision of valuable raw materials for the American economy, and control over rebels and national liberation forces. The third approach: replacement of colonial empires with American military presence in order to solve the same problems.

Keywords: decolonization, public opinion, China, Asia, USA, World War II, press.

Sergey O. Buranok - Dr. Sci. (History), Professor, Samara State University of Social Sciences and Education; 65/67, ul. M. Gorkogo, Samara, 443099, Russian Federation; s.buranok@pgsga.ru

Сергей Олегович Буранок - д-р ист. наук, проф., Самарский государственный социально-педагогический университет, Российская Федерация, 443099, Самара, ул. М.Горького, 65/76; s.buranok@pgsga.ru

The reported study was funded by RFBR, project number 20-39-70003 ("Fighting China" 1931-1949 in the US press estimates).

Статья подготовлена при поддержке гранта № 20-39-70003 Российского фонда фундаментальных исследований («Сражающийся Китай» 1931-1949 гг. в оценках периодической печати США).

(C) St. Petersburg State University, 2020 


\title{
Азия и деколонизация в оценках периодической печати США
}

\author{
С. О. Буранок
}

Для цитирования: Buranok S. O. Evaluation of Asia and Decolonization in the US Press // Вестник Санкт-Петербургского университета. История. 2020. Т. 65. Вып. 4. С. 1186-1201. https://doi.org/10.21638/11701/spbu02.2020.410

Исследования колониальной проблематики в условиях холодной войны невозможны без анализа периодики, издававшейся ее участниками. Изучение прессы второй половины 1945 г. показывает, что смерть Рузвельта не вызвала мгновенного изменения сформированных им взглядов на колониальную систему как на бесперспективную. Не последовало резкой поляризации общественно-политического дискурса, но произошло расширение подходов в средствах массовой информации к теме будущего колоний. Материалы американской прессы 1945 г., посвященные поиску наиболее эффективной и оптимальной стратегии построения отношений как с колониальными империями, так и с зависимыми территориями, показывают, помимо прочего, устойчивый интерес периодических изданий США к негативному и позитивному опыту колониальной политики. Данный опыт вольно или невольно, но постоянно сравнивался в печати с американскими подходами и принципами, создавая устойчивый общественный дискурс, который не только охватывал краеугольные камни международных отношений 1945 г., но и актуализировал практически забытые (особенно в 1941-1944 гг.) индийский вопрос, малайскую и индокитайскую проблемы. Анализируя американскую прессу под этим углом, важно определить и конкретное содержание каждой из «колониальных тем», а также общий настрой редакторов и журналистов применительно к перспективам колониальной системы в 1945 г. и тому практическому опыту, который могут предоставить колониальные империи в новых исторических условиях. В американском общественном дискурсе конца 1945 г. начинает складываться сразу несколько новых подходов к оценке перспектив колониальной системы. Первый подход: сохранение колониальных империй, особенно в ключевых точках послевоенного мира: Ближний Восток, Индокитай, Северная Африка. Второй подход: сохранение Британской колониальной империи, способной (при поддержке США) контролировать Средиземноморье, Ближний Восток, Юго-Восточную Азию, решая тем самым сразу две задачи: сырьевое обеспечение американской экономики, контроль над повстанческими и национальноосвободительными силами. Третий подход: замена колониальных империй американским военным присутствием для выполнения тех же задач.

Ключевые слова: деколонизация, общественное мнение, Китай, Азия, США, Вторая мировая война, периодическая печать.

The questions of the prospects of the colonial system, of the transition into the postcolonial era, of the possibility of application of experience of colonial empires have been actively debated in the American society throughout the recent history ${ }^{1}$. They became

${ }^{1}$ Ashcroft B., Griffiths G., Tiffin H. The Empire Writes Back: Theory and Practice in Post-Colonial Literatures. London; New York, 2010; James-Chakraborty K. Beyond Postcolonialism: New Directions for The History of Nonwestern Architecture // Frontiers of Architectural Research. 2014. No. 3. P. 1-9; Deudney D. Greater Britain or Greater Synthesis: Seeley, Mackinder, and Wells on Britain in the Global Industrial Era // Review of International Studies. 2001. No.27. P.187-208; Chin W. Examining the Application of British Counterinsurgency Doctrine by the American Army in Iraq // Small Wars \& Insurgencies. 2007. No. 1. P. 1-26; Chin W. Colonial Warfare in a Post-Colonial State: British Military Operations in Helmand Province, Afghanistan // Defense Studies. 2010. Vol.10, no. 1-2 (March-June). P. 215-247; Hughes G. The 
especially important in the periods following the Great War (1918-1922) and during the final stage of the World War II (1944-1945) ${ }^{2}$. Studies of the American periodical press will enable us to identify a broader range of models of solutions to the colonial problem compared to the analysis of only the opinions of the expert community and of the diplomatic corps, and, what is most important, - to gain a deeper and more detailed insight into the American conceptions of the practical approaches to the international relations in the context of transformation of the world order at the end of the World War II and directly afterwards ${ }^{3}$.

In the context of a rapid transformation of a modern world order against the background of long military-political destabilization in the Middle East at the beginning of the $21^{\text {st }}$ century, the attention of expert community is increasingly drawn to the phenomenon of an empire. The events happening now, one hundred years after the Sykes-Picot Agreement which laid the foundation of a political configuration of the Middle East shaken today, add relevance to studying the heritage of European colonial empires in practical terms: through the analysis of colonial knowledge and historical modeling of the asymmetric conflicts in the second half of $20^{\text {th }}-$ the beginning of the $21^{\text {st }}$ centuries. The examination of the role of colonial knowledge in military-political planning and forecasting in Great Britain and the USA in the second half of the $20^{\text {th }}$ - the beginning of the $21^{\text {st }}$ centuries will shed light on the theory and practice of the international relations during the transition from an era of global colonial empires to an era of nuclear superpowers, and after "Cold war", in the context of disintegration of bipolar system and contradictions between supporters of the concept of "global leadership" and the multipolar world (the Anglo-Saxon model is of special interest due to its most integral reception of colonial experience of the European powers during a post-colonial era).

With an approach of an era of decolonization and post-colonial researches, the perspective of colonial knowledge plays more and more noticeable role in studying the history of international relations and certain leading powers 4 . In many respects, it is due to the fact that these issues concern not only various directions of historical researches, but also urgent political debates. At the same time, in the past colonial knowledge contributed to strengthening the power of empires, whereas now academic debates about it open up possibilities of making use of the experience of colonial empires in the $21^{\text {st }}$ century ${ }^{5}$.

Insurgencies in Iraq, 2003-2009: Origins, Developments and Prospects // Defence Studies. 2001. No.1. P. 152-176; Egnell R. Winning "Hearts and Minds"? A Critical Analysis of Counter-Insurgency Operations in Afghanistan // Civil Wars. 2010. No. 3. P. 282-303.

2 Tompkins E. B. Anti-Imperialism in the United States: The Great Debate 1890-1920. Philadelphia, 1970.

3 Black G.D., Clayton K. What to show the World: The Office of War Information and Hollywood, 1942-1945 // The Journal of American History. 1977. No. 64. P. 129-144; Donald R. R. Hollywood and World War II. Boston, 1987; Schatz T. Boom and bust: American cinema in the 1940s. University of California Press, 1999.

${ }^{4}$ Engaging Colonial Knowledge. Reading European Archives in World History. Cambridge, 2012.

5 Delpech T. Transatlantic Relations after the War in Iraq // Connections. 2003. No. 3. P. 51-55; Porch D. Occupational Hazards: Myths of 1945 and U. S. Iraq Policy // The National Interest. 2003. No. 72. P. 35-47; Freedman L.D. The Special Relationship, Then and Now // Foreign Affairs. 2006. No. 3. P. 61-73; Dobson A., Steve M. Anglo-American Relations: End of a Special Relationship? // International History Review. 2014. No.4. P. 673-697; Cooper R. The Post-modern State and the world order // Demos. 2002. P.7-43; Cox X. Empire, Imperialism and the Bush Doctrine // Review of International Studies. 2004. No. 30. P. 588-592. 
It should be noted that foreign historiography, as a rule, reflects a recently close connection between the power of the metropole and colonial knowledge through a special analytical prism - the role of army, police and intelligence services as colonial institutes of the British Empire in the process of pacification, social and economic upgrade, and political transformation of its rebellious ownerships ${ }^{6}$.

Modern researchers expand the horizons of historiography by extending beyond traditional studies of the role of armies as a means of expansion and "social elevator" for the subjects of the empire focusing instead on the phenomena of social engineering, colonial knowledge and counterguerrilla fight in their exploration of the military presence in colonies and on the outskirts of the empire 7 .

The materials of the American press of 1945 dedicated to the search for the most efficient strategy of building relations with both colonial empires and dependent territories show, among other things, a steady interest of American mass media towards negative and positive experience of colonial policy ${ }^{8}$. It is to be noted that this experience, intentionally or unintentionally, was constantly compared in the press with American approaches and principles, and in this way shaped a public discourse that encompassed not only the 'cornerstones' of international relations of the year 1945 but actualized the almost forgotten issues (especially in the period of 1941-1944) such as the Malay problem, the Indian question, or the Indo-China problem 9 .

When analyzing the American press from that position, it is very important to identify specific content of each of the 'colonial topics', the general mood of the editors and reporters with respect to the perspectives of the colonial system in 1945 and to the practical experience that might be provided by colonial empires in the new historical context ${ }^{10}$.

${ }^{6}$ Cooper R. Imperial Liberalism // National Interest. 2005. March, 1. P. 101-132; Lake D. A. The New American Empire? // International Studies Perspectives. 2008. No.3. P.281-289; Grandin G. Your Americanism and Mine: Americanism and Anti-Americanism in the Americas // The American Historical Review. 2006. No.4. P.1042-1066; Watenpaugh K.D. The Guiding Principles and the U.S. "Mandate" for Iraq. P. 269-278; Bender T. The American Way of Empire. P.45-61; Conetta C. The Wages of War: Iraqi Combatant and Noncombatant Fatalities in the 2003. Washington, 2003. P.11-15; Mearsheimer J., Walt S. An Unnecessary War. P. 50-59; Keohane R. Governance in a Partially Globalized World. P. 95; Schell J. The Unconquerable World. P. 306.

7 As an example of a traditional view of a role of army in the history of the European empires see: Guardians of Empire: Armed Forces of the Colonial Powers, c. 1700-1964 / eds D. Killingray, D. Omissi. Manchester, 1999.

${ }^{8}$ Lawrence M. The Uses of Vietnam in the Age of Terrorism // International Journal. 2004. No.4. P. 919-928; Killblane R. Lessons Of History // On Point. 2004. No.3. P.18-19; Abramowitz M. Does Iraq Matter? // The National Interest. 2004. No.75. P. 39-44; Yaphe J. S. War and Occupation in Iraq: What Went Right? What Could Go Wrong? // Middle East Journal. 2003. No. 3. P.381-399; Colas A. Open Doors and Closed Frontiers: The Limits of American Empire // European Journal of International Relations. 2008. No. 4. P.619; Alkadry M. G. Reciting Colonial Scripts: Colonialism, Globalization and Democracy in the Decolonized Middle East // Administrative Theory \& Praxis. 2002. No. 4. P.739-762.

${ }^{9}$ Hodge J. M. British Colonial Expertise, Post-Colonial Careering and the Early History of International Development // Journal of Modern European History. 2010. No. 1. P.24-46; Kennedy D. Imperial history and post-colonial theory // The Journal of Imperial and Commonwealth History, 1996. No. 3. P.345-363; Louis W. R., Robinson R. The imperialism of decolonization // The Journal of Imperial and Commonwealth History, 1994. No. 3. P. 462-511; Groen P. Militant Response: The Dutch use of military force and the decolonization of Dutch East Indies 1945-1950 // The Journal of Imperial and Commonwealth History. 1993. Vol.21. P.30-44; Wolfe P. History and Imperialism: A Century of Theory, from Marx to Postcolonialism // The American Historical Review. 1997. No.2. P.388-420.

10 Yavenditti M. American Reaction to the Use of Atomic Bombs to Japan 1945-1947: Ph.D. Dissertation. Berkeley, 1970; Herken G. American Diplomacy and The Atomic Bomb 1945-1947: Ph.D. 
Characterizing features of participation of the leading powers in the local conflicts of the second half of the $20^{\text {th }}$ - the beginning of the $21^{\text {st }}$ centuries, researchers concentrate, as a rule, on explanatory schemes of the theory of the asymmetric conflicts. As a result, political approach doesn't take into consideration the attitude of analysts and experts to the "archive" of colonial knowledge of European empires and does not consider how colonial knowledge has affected the discussion on colonialism. In this regard, the appeal to a role of the colonial knowledge (understood also as experience of empires) in settlement of the asymmetric conflicts in the countries of "the third world" (Anglo-Saxon model) from the methodological point of view is of great importance. At the methodological lev$\mathrm{el}$, it is about new understanding of the role of army, police and intelligence agencies in colonies and the countries of "the third world" in the light of its evaluation by representatives of military-political elite and expert communities within historical modeling of the asymmetric conflicts - at the crossroads of history of colonial knowledge and "modern imperial history", historical science, political science and, actually, military-political analysis. The most evident proof of this tendency is shared terminology and a range of the discussed issues on safety problems. Other characteristic examples include thematic conferences and publications in the leading international magazines on problems of strategy and safety reflecting features of a perspective of the declared subject by the international expert community. The authors of these articles analyze historical precedents, modern forms and methods of counterinsurgency. Actually, these works illustrate historical modeling of the asymmetric conflicts. In this sense, this article enables to address a wider problem of "lessons" of the past. The recent history of the American and British military presence in the Middle East showed inability to comprehend critically and adequately local conditions to apply managerial experience of empires. At the same time, the conversation on institutional features of the army and intelligence agencies in a colonial context centers around a problem of informational support of the efforts aimed at maintenance of order in the recent empires - from ethnographic studies and mapping of subordinate spaces to political investigation, espionage and organization of counter-guerrilla fight. All this shows to what degree colonial practices of Modern and Contemporary times confirm not only the academic, but also social and political relevance of the subject. It should be noted that such scope of the research requires methodological synthesis, both on historiographic and on interdisciplinary levels of modern humanitarian knowledge. This methodological approach to the subject of the article enables to revise conclusions of postcolonial researches about the nature of power of the European imperial expansion; to review traditional views on the connection between evolution of the state institutes of metropoles and colonial policy, to evaluate the role of colonial knowledge in terms of analytical tools of decision making of the leading powers during a post-colonial era, including a method of historical modeling of the asymmetric conflicts.

It is necessary to highlight that that the subject of the analysis is not only opinions expressed in the press and standpoints of experts and politicians but also the colonial problem as a very special phenomenon of intellectual history directly related to the process of decision-making in the external policy of the USA of 1945. This approach can be

Dissertation. Princeton, 1974; Nicholson J. The atomic bomb and Hiroshima historical impact and teaching unit: Ph.D. Dissertation. Chicago, 1980; Paul S. Anglo-American cooperation and the development of the British atomic bomb, 1941-1952: Ph.D. Dissertation. Chicago, 1996; Paulin J. H. America's Decision to Drop the Atomic Bomb on Japan: Ph.D. Dissertation. Shreveport, 2007. 
justified be the fact that the 'colonial discussion' of 1941-1945 involved high dignitaries of state (F. Roosevelt, K. Hull, S. Welles), journalists, and 'experts in international relations' (W. Lippmann, R. Frost, E. Lindley).

The examination of the major aspects of debate on the colonial problem in the American press in 1945, is impossible without shedding some light on the fundamentals underlying that discussion. After the USA had joined the World War II, the global ideological conflict of isolationists and internationalists was transformed into a dispute concerning the extent, the nature and the specifics of the future role of the USA in the world, and the contemporaries saw that as an undeniable defeat of the isolationists. The structure and content of the Atlantic Charter, a programme document directly or indirectly affecting all the participants of the discussion, brought about debates not only among the allies - the USA and Great Britain - but among American journalists as well ${ }^{11}$. The closer the victory over Germany and Japan was, the more frequently the American press turned to the 'colonial problem' ${ }^{12}$.

A special attitude towards this question in 1945 was demonstrated in the article "Colonial Policy" by Ernest Lindley, a reporter of the "Washington Post" who was close to President F.D. Roosevelt. In the article published on 17 January 1945 the author outlined several important points: 1) former colonies in the Pacific Ocean are not only selling markets for American goods; 2) colonies have an utmost importance as sea and air bases; 3) the duty of the USA is not only to protect itself but also the South-East Asia and the Pacific Ocean ${ }^{13}$.

Historians in their analysis of Lindley's article focused on the first two points stating that his views on the Pacific Ocean contradicted those of the Secretary of War Henry Stimson who thought there were no colonies in the isles of the Pacific any longer but only the vanguards of the USA ${ }^{14}$. However, there are several considerations in the article by Lindley that were left out by scholars, e. g. those on "treatment of colonial regions" as one of the most challenging problems in the organization of the world ${ }^{15}$. Rather similar ideas were expressed by the main press organ of the Institute of Pacific Relations in 1945: R. Kennedy, a consultant for the Ethnogeographic Board of the Department of State, called Malaya (the key problem of the South-East Asia), in an article "Colony without Plan" pointed out that it was the configuration and the structure of the British colonial administration that the fate of Singapore and the social, economic, and political processes in the entire Asia depended on ${ }^{16}$.

The situation in Malaya became a starting point for the reflections of a seasoned journalist Lindley who described several important - even global - moments in the 'colonial discussion' still continuing in the American press. In the first place, though, Lindley em-

11 Wichhart S.K. Selling Democracy During the Second British Occupation of Iraq 19411945 // Journal of Contemporary History. 2013. No. 3. P. 509-536.

12 Winfield B. FDR and the News Media. Chicago: University of Chicago, 1990. P.65-67; Mar T. Decolonisation and the Pacific. Cambridge, 2016. P. 125.

13 Washington Post. 1945. Jan., 17. P.9.

${ }_{14}$ Mar T. Decolonisation and the Pacific. Cambridge, 2016. P. 125; Teigrob R. Warming Up to the Cold War: Canada and the United States Coalition of the Willing, from Hiroshima to Korea. Toronto, 2006. P. 193-194.

15 Washington Post. 1945. Jan., 17. P.9.

16 Kennedy R. Malaya: Colony without Plan // Far Eastern Survey. 1945. No. 16. P.225-226. 
phasized the territorial connection of his thoughts with the Pacific; what he had in mind was the entire colonial system.

Secondly, the reporter mentioned "treatment of the system", and this immediately evokes a very understandable set of images in the readers" minds: colonies are "ailing territories" of the day; colonialism is a vicious system; colonies are to be set right. The content of the article leaves no doubt as to who - in Lindley's opinion - is to undertake responsibility for the treatment.

Thirdly, the columnist of "The Washington Post" pointed out that the problem was discussed only sparsely but predicted its global importance in the post war world.

As of 1944-1945, American editors and staff writers quite confidently claimed that the basic colonial experience had long been learned (as early as after the Great War) and that all conclusions had been made from it: it was for that reason that the 'scenarios' of self-governance and self-identification were proposed in so much detail in 1918-1922 and 1944-1945.

However, such an approach towards the colonial issue as well as the British perspective, was in no way acceptable for Arthur Sulzberger, the owner of "The New York Times": on January 21, 1945 the paper published the letter of the American Association of Palestine that called for Great Britain to 'open the Middle East', i. e. to relieve restrictions on the Jewish immigration and to ensure equal opportunities on the territory of Palestine ${ }^{17}$.

Here, we can see a clash of two characteristic approaches towards the problem of colonialism in the American press.

On the one hand, the journalists of the North-western press wrote in 1944-1945 that colonial empires were archaic structures no longer needed in the world of the day, i. e. the authors criticized the general colonial principles and ideas which were not only confined to the British empire in the minds of American journalists. At the very beginning of 1945 colonial systems of the Netherlands, Portugal, and France were criticized in no mild manner ${ }^{18}$.

On the other hand, the discussion of regional aspects of this broad theme (problems of Palestine, India, the Pacific, etc.) had always caused more animated arguments as it touched upon not only the factors of geopolitical, strategic, and moral nature, but also upon economic, social and political motives of representatives of various diaspores of America, public movements and organizations ${ }^{19}$.

Yet in the debates in the press of 1944-1945 the colonial problem did have a solution: the British, French and Dutch empires were collapsing but their structures and even methods were replaced in the international affairs with the union of the "Four Policemen" (the USA, Great Britain, the USSR and China $)^{20}$.

The speeches of President Roosevelt on the "Four freedoms", the comments on the Atlantic Charter and on the conferences in Casablanca, Cairo and Tehran show a gradual formation not only of a view of the future world, interaction of allies, fate of Europe, but also on the prospects of the colonial system: transition from colonial methods in the in-

17 New York Times. 1945. Jan., 21. P. 1.

18 Chicago Tribune. 1945. Jan., 19. P. 10; Bianchi J. Portugal's colonial policy // World Affairs. 1944. No. 2. P. 96-100.

19 Arrighi G., Silver B. Capitalism and World (Dis)order // Review of International Studies. 2001. Vol.27, no. 5. P.257-279.

20 Bosco D. Five to Rule Them All: The UN Security Council and the Making of the Modern World. Oxford, 2009. 
ternational policy towards the implementation of American principles in the economy for the 'large and small nations' and the international control under the auspices of the "Four Policemen" instead of a mandate system ${ }^{21}$. However, as Lawrence Freeman notices, "Roosevelt knew the war had to be won with the British as allies, but his diplomacy, while he was conducting the war, was premised on the future, which his grand strategy embodied. After the war, he intended to bring into existence a new anti-imperialist alliance, which, unfortunately his untimely death, and the succession of Truman as President, tragically aborted. Roosevelt's vision was to have a new alliance comprised of the United States, Russia, and China, the three most powerful nations, which did not have colonial possessions against the British, French, and Dutch colonial powers"22.

The analysis of the press of the second half of 1945 shows that Roosevelt's views on the colonial system as one with no future did not disappear immediately; his death did not cause a sharp polarization of social and political discourse, but there emerged a change in the approaches of the mass media towards the future of the colonies. Some of the very illustrative international events demonstrating the presence of several approaches to the colonial system inside the USA were the San Francisco Conference of 1945, the Potsdam Conference, and the capitulation of Japan. The American press identified the standpoints of the major participants of the discussion during this very eventful period. These poles to which the public opinion was attracted were the position of S. Welles, the position of W. Lippmann, and the position of R. Frost.

In the second half of April 1945 Robert McCormick devoted pages of "Chicago Tribune" to a consistent critique of not some aspects of the colonial problem but of the whole system. On April 16, 1945 "Chicago Tribune" published the article reflecting the viewpoint of S. Welles. The former Deputy of the U.S. Secretary of State wrote that if the San Francisco Conference was to bring peace, the question of colonies should be on its agenda ${ }^{23}$. However, the approach of S. Welles differed from that of Lippmann that had been better known in the USA; it was with the latter that the diplomat argued in the article. Lippmann stated that the interests of the United States in Wales, Alaska, in Hawaii, in Puerto Rico and in the Virgin Islands required very careful tackling of the colonial issue. Welles argued that the question of military bases needed for the national security was different from that of colonies. The occupation of territories (intended for the military bases) affected, in Welles's words, lives of several thousand people, whereas colonial expansion involved millions ${ }^{24}$. To provide additional arguments, Welles used the moral appeals and the logic saying that national defense had nothing to do whatsoever with the tyranny unfolded by Great Britain worldwide ${ }^{25}$. In that article, and in many others on the future of the colonies,

21 Behre C. H. Mineral Resources and the Atlantic Charter // Geographical Review. 1943. No. 3. P. 482486; Knight M. M. The Atlantic Charter and Africa from an American Standpoint // Political Science Quarterly. 1943. No.1. P. 141-142; Wright Q. United Nations-Phrase or Reality? // The Annals of the American Academy of Political and Social Science. 1943. Vol.228. P. 1-10; The Problem of British Security // International Affairs. 1944. No.3. P. 390-401; Messer R. The End of an Alliance: James F. Byrnes, Roosevelt, Truman, and the Origins of the Cold War. Chapel Hill, 1982; Yergin D. Shattered Peace: The Origins of the Cold War and the National Security State. New York, 1978.

22 Freeman L. K. Roosevelt's 'Grand Strategy' to Rid the World of British Colonialism: 1941-1945 // The American Almanac, July 14, 1997. URL: http://american_almanac.tripod.com/lkffdr.htm (accessed: 17.02.2020).

23 Chicago Tribune. 1945. Apr., 16. P. 14.

24 Ibid.

25 Ibid. 
Welles consistently elaborated on the proposals of Woodrow Wilson adjusting them not only to the reality of 1940s but also comparing them with his own experience of Latin America.

In this publication, the former Deputy of the U.S. Secretary of State continued developing the theory of necessity of providing independence to the colonial nations under the auspices of an international agency ${ }^{26}$. Using this argument (desire of the colonial nation) Welles arrived at broader conclusions: "the Eastern races are determined to end their subjugation to the West. They are demanding liberty and self-government"27. Here, Welles not only provided a justification for the opposition between the East and the West in the context of colonial issues, but also made a direct transfer of the American political experience to the "Eastern races" ('Eastern' meaning 'colonial' in this context), and proposed that the use of methods tried and tested in the history of the USA might not cure the colonial system: it had to be disposed of.

In his articles Welles came across as a supporter of views of Franklin Roosevelt, sometimes making them more radical and warning the future UN against backing up colonial methods. In order to create a specific public opinion and mood before the San Francisco Conference, Robert McCormick went beyond publishing only the position of Welles. On April 21, 1945 "Chicago Tribune" printed the article "A new deal for New Guinea" raising more global problems of the colonial system despite the headline: "Next week we are to witness the convening of a solemn conclave in San Francisco, one of the purposes of which is to establish a world economic and social council, which, in the language of Dumbarton Oaks, "should facilitate solutions of International economic, social, and other humanitarian problems; respect for human rights and fundamental freedoms".

We should suppose that if Australia and the other colonial powers really wanted to do anything toward ameliorating the lot of their exploited natives a less cumbersome method might be found. The scheme, as it stands, is admirably adapted to maintaining slavery and peonage in New Guinea until it is abolished in Java, Indo-China, Malaya, and everywhere else. That may be a very long time, Indeed, because the prime purpose of the colonial system Is the exploitation of men"28.

This extensive quote shows that Welles connected the resolution of colonial problems of European states with a combination of two important factors: market economy and American social (more globally, humanitarian) principles, the basics of which were to become human rights ${ }^{29}$. Such a position of Welles brings him closer in his economic approach to the principles of K. Hull expressed as early as in 1941: limitation of economic nationalism of the empires; elimination of discrimination in the international trade; generally available sources of raw materials; creation of a system of international finance in order to foster entrepreneurship worldwide.

In this regard, the views of S. Welles are similar to those of $\mathrm{H}$. Gilchrist who had been dealing with problems of the mandate system in the League of Nations before the war. In October 1945 Gilchrist published an article on the colonial problem in "The American Political Science Review"; in it he wrote that the negative experience of administering

\footnotetext{
26 The Washington Post. 1945. March, 28. P. 8.

27 Ibid. Oct., 24. P. 4.

28 Chicago Tribune. 1945. March, 21. P. 10.

29 Blouet B. W. Geopolitics and Globalization in the Twentieth Century. London, 2001. P. 125-133.
} 
colonies of several European countries became the reason for numerous discussions ${ }^{30}$. Gilchrist proved that colonies were not problems of specific states but rather an international problem, and that the USA having liberated the majority of colonies by the force of their weapons, now had a decisive vote in the identification of their future: modernization of governance, self-identification and self-governance.

Therefore, the main lesson taken by both S. Welles and H. Gilchrist from the history of World War II, experience of colonial empires and the history of colonialism, the lesson that could have been used in the then current conditions was to give to the colonies their own "Bills of Rights" before an explosion of revolutions. In April 1945, Welles expanded his project onto the whole world by emphasizing the global character of his views twice in a small article.

The tone of Welles's articles shows a clear understanding of the fact the resolution of colonial problems was to be undertaken by the USA since the existing colonial empires wanted to do nothing to improve the situation ${ }^{31}$. The former Deputy of the U.S. Secretary of State directly contrasted negative colonial experience (slavery, peonage, exploitation) to the positive American experience (human rights and basic freedoms).

In his regular column "Today and Tomorrow" and in separate articles, Walter Lippmann argued both with proposals of Wilsonism and with isolationists; by 1944-1945 he had amassed general recognition as the "trend-setter" in the questions of international policy. Lippmann's attention was focused on the questions of the world order after the war, special features of relations between the USA and the USSR, and assistance to Europe. In 1945, Lippmann analyzed the prospects of colonial system using the same basic principles as Welles did: economy, political freedoms, and the possibility of applying American experience to the colonies, and, at the same time, the possibility of applying colonial experience of the USA ${ }^{32}$.

Whereas the logic of Welles's reflections was from liberal economic principles towards economic postulates, Lippmann's articles demonstrated a reversed way. In the spring of 1945 in several publications in the "Today and Tomorrow" column, Lippmann justified his views on the future of the whole colonial system and on its British part. The writer expressed his concerns that the American money allocated to assist Great Britain would in fact be used to "support the archaic colonial system" thereby inflicting three major blows on America: she would spend substantial money, would miss the opportunities of affecting 'colored races' and would strongly restrict its own progress in the international trade ${ }^{33}$.

Based on that, in May 1945 Lippmann arrived at the conclusion that the task of the USA - at least, in the Americano-British context of the colonial issue - was to replace Great Britain in the international trade by becoming the main "guardian, regulator and promoter" 34 . The journalist gave a direct comparison: the $20^{\text {th }}$ century USA was to "inherit the functions of the $19^{\text {th }}$ century Britain". This was not only the analysis of the negative colonial experience that Welles focused on; Lippmann questioned not only the succession

30 Gilchrist H. Colonial Questions at the San Francisco Conference // The American Political Science Review. 1945. No. 5. P.982-992.

31 Hanson G. Ordeal Liberty: Sumner Welles and the Crowder Welles Connection in the Caribbean // Diplomatic History. 1994. No. 13. P.312.

32 Robinson N. Problems of European Reconstruction // The Quarterly Journal of Economics. 1945. No. 1. P. 51-55.

33 The Washington Post. 1945. March, 20. P.3.

${ }^{34}$ Ibid. May, 26. P. 2. 
of that experience but its direct transfer onto the modern international context. The situation was somehow balanced by the fact that in those articles Lippmann reflected only on one aspect of the "Britain's imperial legacy", i. e. the experience in regulating international trade, whereas for colonial methods of administration he used conventional language ("archaic system") for the spring of 1945.

However, in October and November 1945 the focus of Lippmann's attention began to shift from purely economic questions of the prospects of colonial empires onto political ones. The journalist wrote about the end of the British imperial history when the resources of colonies supported the "glory of the Empire" and ensured their own subsistence at the same time. After the victory, in Lippmann's opinion, a new historical period started when Great Britain owed its colonies - not only economically but morally as well. The empire now faced a very costly prospect: numerous internal uprisings with the necessity of using the force in mitigating them in the context of a very grave economic situation ${ }^{35}$. The conclusion he drew was as follows: unless nothing was changed, the British Empire would transform from a donor for Great Britain into a consumer of British resources.

Such conclusions of Lippmann were well received in the informational realm of the second half of 1945 when a discussion was underway on the cost of assisting Europe and whether or not that assistance could undermine the economic foundation of America ${ }^{36}$.

Another reporter and expert, R. Frost, was developing his ideas in a similar direction as Lippmann but he had founded them on the comparison between the contemporary British experience (first of all, parliamentary discussions of 1943) and historical experience. Frost wrote that both the Secretary of State for the Colonies O. Stanley and the Parliament identified the main principle of administration in colonies as "patronage". Frost was openly puzzled as to how that could be possible in the present conditions for the 'patronage' had been in place for over a century. He concluded that the British Empire was in need of one more economic stress to understand that active contribution to social and economic stability was required as a preparatory step for the development of self-governance. In order to change Britain's approaches towards colonial economy, radical changes in the country's political philosophy were likewise needed ${ }^{37}$. Frost's ideas on the prospects of colonial empires resembled the position taken by Lippmann, but Frost emphasized, to a larger extent, the conceptualization of the British experience and proved its invalidity in the contemporary world.

Lippmann suggested looking at the same issue from a different angle: the American economic assistance might be used by the colonial empires to preserve their status. That would hit the US with unfavorable tariffs and, in a longer run, would provoke uprisings in the colonies that might be used by the Soviet Union to politically redirect colonial nations of Asia and Africa.

The last argument was developed in newspaper publications not only by Lippmann but by Ernest Lindley as well. He also questioned the consequences of fast decolonization: could it be that the support of colonial empires would turn out to be a more productive and effective means (in Lindley's opinion) of supporting international security? ${ }^{38}$ Throughout 1945 Lindley was careful to avoid extreme judgements of the prospects of the

\footnotetext{
35 The Washington Post. 1945. Oct., 30. P.3.

36 Chicago Tribune. 1945. Jul., 21. P. 1.

37 Frost R. A. Reflections on British Colonial Policy // Pacific Affairs. 1945. No. 4. P. 309-320.

38 The Washington Post. 1945. Jan., 17. P.3.
} 
colonial system and focused the readers' attention on the fact that nobody ever thought of giving full freedom to all nations in the Middle and in the Far East ${ }^{39}$.

Sulzberger was similarly careful when giving his views on this aspect of the colonial system from the pages of "The New York Times". His articles on the crisis in Algeria explicitly or implicitly raised the question whether the complete withdrawal of France from Northern Africa would result in a fast destabilization of the entire region and whether it would cause uprisings and revolutions ${ }^{40}$ ? Sulzberger proclaimed that "the most important political development during the last ten years... has been the emergence of the Union of Soviet Socialist Republics as the greatest dynamic and diplomatic force on the vast Eurasian landmass which stretched from the Atlantic to the Pacific oceans". This cautious attitude was characteristic of the publications by Lippmann (resulting in a discussion with S. Welles): on the one hand, he refrained from defining a colonial regime as 'obsolete' to avoid identification of "our own regime" in the same way; nevertheless, it was not possible to regard in one and the same manner all anti-Soviet processes (including those in the colonies) as democratic and pro-western ${ }^{41}$.

It is possible to state that in 1944-1945 the majority of most reputable and widely read journalists in the USA focused on the European policy that was pursued by the White House, by the Department of State and by the mass media as the cornerstone of the American foreign policy. Therefore, the views on the colonial system and the models of solution to the colonial question were formed in the USA, on the one hand, under a very direct influence of the European factor of international relations. Lippmann, Lindley, Welles, and Sulzberger used a whole range of arguments to prove the necessity of transformation or dissolution of colonial empires - arguments referring to the European policy (the European states would find liquidation of colonies beneficial; Europe would receive economic aid from the USA; Europe was using unpopular and obsolete methods of administration). Some way or another, the center of the colonial issue was the European policy of the USA, and the principles of the Atlantic Charter, rights and freedoms of colonial nations and self-identification of nations seemed to the journalists only the means for establishing a new system of relations between the USA and Europe.

On the other hand, the articles of the above-mentioned politicians and journalists demonstrated a different factor of influence on the establishment of approaches towards the colonial question: the attention of the Soviet Union towards national liberation movements in Asia and Africa. An especially rapid impact of this factor was evident in the publications of the autumn of 1945 when both Lindley and Lippmann started discussing the negative outcomes of decolonization and indicated that the downfall of empires would undoubtedly open new markets for the USA but, at the same time, the "political vacuum" in the colonies might be quickly occupied by the communists or, in a different scenario, the radical liberation process in colonies might undermine Europe's economy, and the Europeans might be moved forward to communism - first economically, and then morally and politically ${ }^{42}$.

Thus, there emerged several new approaches towards evaluation of the prospects of the colonial system in the American public discourse in late 1945. The first approach: re-

\footnotetext{
39 Ibid.12.07. P. 7.

40 New York Times. 1945. Jun., 8. P. 5; Ibid. Jul., 12. P. 5.

41 The Washington Post. 1945. Oct., 30. P. 2; Ibid. 1946. Feb., 28. P. 9.

42 The Washington Post. 1945. Oct., 30. P. 2
} 
tention of all colonial empires, especially in the key points of the after-war world (Middle East, Indochina, Northern Africa). The second approach: retention of the British colonial empire capable of controlling (with the aid from the USA) the Mediterranean area, the Middle East, and the South-Eastern Asia, which would address two tasks, namely, provision of valuable raw materials for the American economy and control over rebels and national liberation forces ${ }^{43}$. The third approach: replacement of colonial empires with American military presence in order to solve the same problems. The second and third approaches inevitably led to the actualization of more complex questions in the American social and academic discourse: what type of military operations such support would require from the USA; what the configuration of military and political planning would be like; what the global prospect of a possible military intervention of the USA in the processes in the South-Eastern Asia and in the Middle East would be. In other words, at the very end of 1945, the leading American journalists writing on the colonial theme arrived at the formulation of a very complicated multi-faceted problem: that of historical modelling of asymmetric conflicts in the "Third World countries" in the context of the unfolding Cold War and in the context of experience of global colonial empires ${ }^{44}$.

In 1945, these approaches were only taking shape. Their broad discussion in state agencies, expert community and the mass media would take place in 1946-1949. Yet each of the new models required a new ideological foundation for discussion, new understanding of economic, social and humanitarian knowledge, and new analysis of the colonial experience $^{45}$.

\section{References}

Abramowitz M. Does Iraq Matter? The National Interest, 2004, no. 75, pp. 39-44.

Alkadry M. G. Reciting Colonial Scripts: Colonialism, Globalization and Democracy in the Decolonized Middle East. Administrative Theory \& Praxis, 2002, no. 4, pp. 739-762.

43 Hodge J. M. British Colonial Expertise, Post-Colonial Careering and the Early History of International Development. P. 24-46; Kennedy D. Imperial history and post-colonial theory. P.345-363; Louis W.R., Robinson R. The imperialism of decolonization. P. 462-511; Wolfe P. History and Imperialism: A Century of Theory, from Marx to Postcolonialism. P.388-420; Blackwell S. Between Tradition and Transition: State Building, Society and Security in the Old and New Iraq // Middle Eastern Studies. 2005. No. 3. P.445-452; Cumings B. What is in a Rim? Critical Perspectives on the Pacific Region Idea. Boulder, 1993; Arrighi G., Silver B. Capitalism and World (Dis)order. P. 257-279; McCormick T. America's Half-Century: United States Foreign Policy in the Cold War and After. Baltimore, 1995. P.51; Ludden D. America's Invisible Empire // Economic and Political Weekly. 2004. No.44. P.4776-4777; Seymour M. Ancient Mesopotamia and Modern Iraq in the British Press, 1980-2003 // Current Anthropology. 2004. No. 3. P. 351-368.

44 Shimko K. Metaphors and Foreign Policy Decision Making // Political Psychology. 1994. Vol. 15, no. 4. P.655-671; Campbell S. The Role of Metaphors in U.S. Foreign Policy: Global Leadership and the Carter Administration // American International Journal of Social Science. 2015. Vol. 4. P. 1-10; Brenner P. The power of metaphor: Explaining U.S. policy toward Cuba // Diplomatic History. 2010. No. 2. P. 439-445.

45 Nelson J., Adams G., Branscombe N., Schmitt M. The role of historical knowledge in perception of race-based conspiracies // Race and Social Problems. 2010. No.2. P.69-80; Stempel C., Hargrove T., Stempel G. Media use, social structure, and belief in 9/11 conspiracy theories. P.353-372; Hitchens C. Unfairenheit 9/11: The lies of Michal Moore. P. 52-64; Manwell L. In denial of democracy. P. 848-884; Swami V., Chamorro-Premuzic T., Furnham A. Unanswered questions: A preliminary investigation of personality and individual difference predictors of 9/11 conspiracist beliefs // Applied Cognitive Psychology. 2010. No.6. P. 749-761; Wood M., Douglas K. "What about building 7?": A social psychological study of online discussion of 9/11 conspiracy theories. P. 1-9. 
Arrighi G., Silver B. Capitalism and World (Dis)order. Review of International Studies, 2001, vol. 27, no. 5, pp. 257-279.

Ashcroft B., Griffiths G., Tiffin H. The Empire Writes Back: Theory and Practice in Post-Colonial Literatures. London, Routledge, 2010, 352 p.

Behre C. H. Mineral Resources and the Atlantic Charter. Geographical Review, 1943, no. 3, pp. 482-486.

Bender T. The American Way of Empire. World Policy Journal, 2006, no. 1, pp.45-61.

Black G. D., Clayton K. What to show the World: The Office of War Information and Hollywood, 19421945. The Journal of American History, 1977, no. 64, pp. 129-144.

Blackwell S. Between Tradition and Transition: State Building, Society and Security in the Old and New Iraq. Middle Eastern Studies, 2005, no. 3, pp.445-452.

Blouet B. W. Geopolitics and Globalization in the Twentieth Century. London, Reaktion Books, 2001, 512 p.

Bosco D. Five to Rule Them All: The UN Security Council and the Making of the Modern World. Oxford, Oxford University Press, 2009, 388 p.

Bianchi J. Portugal's colonial policy. World Affairs, 1944, no. 2, pp.96-100.

Chin W. Colonial Warfare in a Post-Colonial State: British Military Operations in Helmand Province, Afghanistan. Defense Studies, 2010, vol. 10, no. 1-2 (March-June), pp. 215-247.

Chin W. Examining the Application of British Counterinsurgency Doctrine by the American Army in Iraq. Small Wars \& Insurgencies, 2007, no. 1, pp. 1-26.

Colas A. Open Doors and Closed Frontiers: The Limits of American Empire. European Journal of International Relations, 2008, no. 4, pp.618-629.

Conetta C. The Wages of War: Iraqi Combatant and Noncombatant Fatalities in the 2003. Washington, PDA, 2003, 112 p.

Cooper R. Imperial Liberalism. National Interest, 2005, no. 1, pp. 101-132.

Cooper R. The Post-modern State and the world order. Demos, 2002, pp.7-43.

Cox X. Empire, Imperialism and the Bush Doctrine. Review of International Studies, 2004, no. 3, pp. 588-592.

Cumings B. What is in a Rim? Critical Perspectives on the Pacific Region Idea. Boulder, Westview Press, 1993, $318 \mathrm{p}$.

Delpech T. Transatlantic Relations after the War in Iraq. Connections, 2003, no. 3, pp. 51-55.

Deudney D. Greater Britain or Greater Synthesis: Seeley, Mackinder, and Wells on Britain in the Global Industrial Era. Review of International Studies, 2001, no. 27, pp. 187-208.

Dobson A., Steve M. Anglo-American Relations: End of a Special Relationship? International History Review, 2014, no. 4, pp. 673-697.

Donald R. R. Hollywood and World War II. Boston, University of Massachusetts, 1987, 429 p.

Egnell R. Winning "Hearts and Minds"? A Critical Analysis of Counter-Insurgency Operations in Afghanistan. Civil Wars, 2010, no.3, pp.282-303.

Engaging Colonial Knowledge. Reading European Archives in World History. Cambridge, Cambridge University Press, 2012, 408 p.

Freedman L. D. The Special Relationship, Then and Now. Foreign Affairs, 2006, no. 3, pp.61-73.

Frost R. A. Reflections on British Colonial Policy. Pacific Affairs, 1945, no. 4, pp. 309-320.

Gilchrist H. Colonial Questions at the San Francisco Conference. The American Political Science Review, 1945, no. 5, pp.982-992.

Grandin G. Your Americanism and Mine: Americanism and Anti-Americanism in the Americas. The American Historical Review, 2006, no. 4, pp. 1042-1066.

Groen P. Militant Response: The Dutch use of military force and the decolonization of Dutch East Indies 1945-1950. The Journal of Imperial and Commonwealth History, 1993, vol.21, pp.30-44.

Guardians of Empire: Armed Forces of the Colonial Powers, c. 1700-1964. Eds D. Killingray, D. Omissi. Manchester, Manchester University Press, 1999, 422 p.

Hanson G. Ordeal Liberty: Sumner Welles and the Crowder Welles Connection in the Caribbean. Diplomatic History, 1994, no. 13, pp.312-325.

Herken G. American Diplomacy and The Atomic Bomb 1945-1947: Ph. D. Dissertation. Princeton, 1974, $511 \mathrm{p}$.

Hitchens C. Unfairenheit 9/11: The lies of Michal Moore. Slate, 2004, no. 6, pp. 52-64. 
Hodge J.M. British Colonial Expertise, Post-Colonial Careering and the Early History of International Development. Journal of Modern European History, 2010, no. 1, pp. 24-46.

Hughes G. The Insurgencies in Iraq, 2003-2009: Origins, Developments and Prospects. Defence Studies, 2011, no. 1, pp. 152-176.

James-Chakraborty K. Beyond Postcolonialism: New Directions for The History of Nonwestern Architecture. Frontiers of Architectural Research, 2014, no. 3, pp.1-9.

Kennedy D. Imperial history and post-colonial theory. The Journal of Imperial and Commonwealth History, 1996, no. 3, pp. 345-363.

Kennedy R. Malaya: Colony without Plan. Far Eastern Survey, 1945, no. 16, pp. 225-226.

Keohane R. Governance in a Partially Globalized World. American Political Science Review, 2001, no.1, pp. 92-107.

Killblane R. Lessons of History. On Point, 2004, no. 3, pp. 18-19.

Knight M.M. The Atlantic Charter and Africa from an American Standpoint. Political Science Quarterly, 1943, no. 1, pp.141-142.

Lake D. A. The New American Empire? International Studies Perspectives, 2008, no. 3, pp. 281-289.

Lawrence M. The Uses of Vietnam in the Age of Terrorism. International Journal, 2004, no. 4, pp.919-928.

Louis W. R., Robinson R. The imperialism of decolonization. The Journal of Imperial and Commonwealth History, 1994, no. 3, pp.462-511.

Ludden D. America’s Invisible Empire. Economic and Political Weekly, 2004, no. 44, pp.4776-4777.

Manwell L. In denial of democracy: Social psychological implications for public discourse on state crimes against democracy post-9/11. American Behavioral Scientist, 2010, no. 6, pp. 848-884.

Mar T. Decolonisation and the Pacific. Cambridge, Cambridge University Press, 2016, 387 p.

McCormick T. America's Half-Century: United States Foreign Policy in the Cold War and After. Baltimore, Johns Hopkins University Press, 1995, 602 p.

Mearsheimer J., Walt S. An Unnecessary War. Foreign Policy, 2003, no. 1, pp. 50-59.

Messer R. The End of an Alliance: James F. Byrnes, Roosevelt, Truman, and the Origins of the Cold War. Chapel Hill, University of North Carolina Press, 1982, 457 p.

Nelson J., Adams G., Branscombe N., Schmitt M. The role of historical knowledge in perception of racebased conspiracies. Race and Social Problems, 2010, no. 2, pp. 69-80.

Nicholson J., Wray H. The atomic bomb and Hiroshima historical impact and teaching unit: Ph. D. Dissertation. Chicago, 1980, $336 \mathrm{p}$.

Paul S. Anglo-American cooperation and the development of the British atomic bomb, 1941-1952: Ph. D. Dissertation. Chicago, 1996, $384 \mathrm{p}$.

Paulin J.H. America's Decision to Drop the Atomic Bomb on Japan. Louisiana State University in Shreveport: Ph. D. Dissertation. Chicago, 2007, 402 p.

Porch D. Occupational Hazards: Myths of 1945 and U. S. Iraq Policy. The National Interest. 2003, no. 72, pp.35-47.

Robinson N. Problems of European Reconstruction. The Quarterly Journal of Economics. 1945, no. 1, pp. 5155.

Schatz T. Boom and bust: American cinema in the 1940s. Los Angeles, University of California Press, 1999, $362 \mathrm{p}$.

Schell J. The Unconquerable World. Harper's Magazine, 2003, no. 3, pp.301-311.

Seymour M. Ancient Mesopotamia and Modern Iraq in the British Press, 1980-2003. Current Anthropology, 2004, no.3, pp.351-368.

Stempel C., Hargrove T., Stempel G. Media use, social structure, and belief in 9/11 conspiracy theories. Journalism and Mass Communication Quarterly, 2007, no. 2, pp.353-372.

Swami V., Chamorro-Premuzic T., Furnham, A. Unanswered questions: A preliminary investigation of personality and individual difference predictors of 9/11 conspiracist beliefs. Applied Cognitive Psychology, 2010, no. 6, pp. 749-761.

Teigrob R. Warming Up to the Cold War: Canada and the United States Coalition of the Willing, from Hiroshima to Korea. Toronto, University of Toronto Press, 2006, 404 p.

Tompkins E. B. Anti-Imperialism in the United States: The Great Debate 1890-1920. Philadelphia, University of Pennsylvania Press, 1970, 421 p. 
Watenpaugh K. D. The Guiding Principles and the U.S. "Mandate" for Iraq: Twentieth-Century Colonialism and Ameri-ca's New Empire. The Logos Reader: Rational Radicalism and the Future of Politics. Louisville, University Press of Kentucky, 2006, pp. 269-278.

Wichhart S.K. Selling Democracy During the Second British Occupation of Iraq 1941-1945. Journal of Contemporary History, 2013, no. 3, pp. 509-536.

Winfield B. FDR and the News Media. Chicago: University of Chicago, 1990, 384 p.

Wolfe P. History and Imperialism: A Century of Theory, from Marx to Postcolonialism. The American Historical Review, 1997, no. 2, pp.388-420.

Wood M., Douglas K. "What about building 7?": A social psychological study of online discussion of 9/11 conspiracy theories. Frontiers in Psychology, 2013, no. 4, pp. 1-9.

Wright Q. United Nations-Phrase or Reality? The Annals of the American Academy of Political and Social Science, 1943, vol. 228, pp. 1-10.

Yaphe J.S. War and Occupation in Iraq: What Went Right? What Could Go Wrong? Middle East Journal, 2003, no. 3, pp.381-399.

Yavenditti M. American Reaction to the Use of Atomic Bombs to Japan 1945-1947: Ph. D. Dissertation. Berkeley, 1970, $411 \mathrm{p}$.

Yergin D. Shattered Peace: The Origins of the Cold War and the National Security State. New York, Houghton Mifflin, 1978, 392 p.

\footnotetext{
Статья поступила в редакцию 5 марта 2020 г.

Рекомендована в печать 9 сентября 2020 г.

Received: March 5, 2020

Accepted: September 9, 2020
} 